\title{
THE NON-PROFIT CORPORATION OR ASSOCIATION IN THE NON-AGRICULTURAL FIELD
}

\author{
Raymond W. Mtrler* and Herbert R. Grossman†
}

This article is a factual presentation of the use in the business world of the nonprofit corporation and association in the non-agricultural field. No attempt will be made to cover every type of business, but leading examples only will be discussed to bring out instances where the corporation and association act as agents on a non-profit or cooperative basis primarily for the benefit of their members and patrons. The matter presented is intended merely as a guidepost pointing the various directions in which such organizations are journeying and is not a recommendation as to the direction that business should take.

The corporation has until recently been operated primarily for the pecuniary profit of its stockholders. ${ }^{1}$ Beginning with the philosophy of the now famous adventure of the Rochdale pioneers in England in 1844, a new concept of doing business has developed--the doing of business on a non-profit or cooperative basis.

It should be fully recognized that the theory of the non-profit or cooperative entities is to employ the corporation or association as an instrumentality which, making no gain for itself, serves its stockholders or patrons to the end that their profits may be increased or their expenses lessened. The chief reason for forming such bodies is to enable individuals or companies to accomplish jointly, through the corporate agent, what they cannot achieve singly or severally in competition with each other.

The Associated Press ${ }^{2}$ and the Canadian Press ${ }^{3}$ are two prominent non-profit

- Member of the Mississippi bar. President and General Counsel, American Institute of Cooperation, 1944-1947. Member of the Committee on Statement of the Law of Cooperatives, Division on Cooperative Corporations, American Bar Association, 1947.

+Member of the Virginia, Kentucky, and District of Columbia bars. Professor of Law and Assistant Dean, Southeastern University Law School, 1925-1941. Associate General Counsel, American Institute of Cooperation, 1945-1947.

${ }^{2}$ In the leading case of Dodge v. Ford Motor Company, 204 Mich. 459, 170 N. W. 668 (1919), noted in 17 Mrct. LAW REv. 502 (1919) the court stated: "A business corporation is organized and carried on primarily for the profit of the shareholders. The powers of the directors are to be employed for that end. The discretion ... does not extend to ... the reduction of profits, or to the nonbistribution of profits among stockholders in order to devote them to other purposes." Id. at 684 .

'See Associated Press v. United States, 326 U. S. I (1945). This was a civil action wherein the United States successfully enjoined the Associated Press, composed of newspaper publishers, from combining cooperatively to violate the Sherman Antitrust Act. The opinion of the Court brought out the fact that the publishers of more than 1200 newspapers comprised the membership of the Associated Press and that it was a non-profit cooperative association incorporated under the membership corporation law of the state of New York. In the majority opinion, Mr. Justice Black significantly pointed out: "We need not again pass upon the contention ... that because AP's activities are cooperative, they fall outside the sphere of business. ... When Congress has desired to permit 
corporations the prime purpose of which is to act as service agents for their members. The Washington, D. C., Clearing House Association is a voluntary, nonprofit, unincorporated association of member banks existing solely for the purpose of rendering service in the clearing of checks of all Washington banks and for the general welfare of its members. This is generally true of bank clearing houses. Most of the stock and commodity exchanges throughout the country are non-profit associations, and, unlike ordinary business corporations, do not operate for pecuniary gain. ${ }^{4}$

The American Institute of Banking, a section of the American Bankers Association, is a voluntary, non-profit, educational institution. Its object is effectively to train bank employees in theoretical and practical principles of banking and allied subjects.

Public utilities have found that the non-profit corporation is a valuable purchasing agent for use by power companies in the joint acquisition of goods. For example, the operating subsidiaries of Engineers Public Service Company (Delaware) obtain economies and more efficient service through group operation of certain essential services, including executive, advisory, purchasing, sales promotion, insurance, accounting, statistical, tax, and corporate services. These services are furnished on a non-profit basis by Engineers Public Service Company, Inc. (New York), a mutual service organization wholly owned by the operating subsidiaries of Engineers Public Service Company. ${ }^{5}$

Non-profit contract chain organizations have met the competition of the integrated corporate chain stores. Thousands of independently owned grocery stores have set up central wholesale purchasing non-profit corporations which have enabled them to compete with the far-flung activities of the single corporate-operated

cooperatives to interfere with the competitive system of business, it has done so expressly by legislation." Id. at I4.

A statute allowing the formation of corporations not for profit without capital stock is not confined to religious, literary, or charitable corporations, or those of a similar nature, but applies to any corporation not for profit. See, e.g., Read v. Tidewater Coal Exchange, 13 Del. Ch. 195, x16 Atl. 898 (1922) (coal dealer's exchange agency to facilitate coal handling); McClure v. Cooperative Elevator \& Supply Co., I05 Kan. 9I, 181 Pac. 573 (1919); Equity Cooperative Packing Co. v. Hall, 42 N. D. 523, 173 N. W. 796 (1919). A "mutual company" is one wherein the members constitute both the insurer and the insured, where the members all contribute, by a system of assessments, to the creation of a fund from which all losses and liabilities are paid, and wherein the profits are divided among themselves in proportion to their interests. State v. Willett, 17r Ind. 296,86 N. E. 68 (Ig08). Pennsylvania statutes, similar to those in a great many states, permit the creation of a non-profit corporation "for any purpose or purposes which are lawful and are not injurious to the community." Pub. L. 289, Art. II, 5201, May 5, 1933.

i The Canadian Press is a cooperative news-gathering and distributing association of the Canadian daily papers. It is the first cooperative news association in the Empire. This enterprise sells nothing, makes no profits, declares no dividends, owns no buildings or property except the furniture and fixtures in its bureaus, and is governed by the basic cooperative principle of "one paper-one vote." Ford, The Canadian Press, Canadian Business, January $1,1947$.

'Dickinson v. Board of Trade, II4 Ill. A. 295 (1904); Constitution of the New York Stock Exchange, Art. I, \$2; In re Haebler v. New York Produce Exchange, 149 N. Y. 414,44 N. E. 87 (1896); White v. Browncll, 3 Abb. Pr. (N. S.) [N. Y.] 318 (1868) (aff'd 2 Daly 329); Crane, Parris \& Co., v. Clearing House Ass'n, 2 Pa. Dist. 509 (1893).

${ }^{5}$ Financial and Statistical Report for the year 1944, Engineers Public Service Company (Delaware). 
multiple-outlet chain stores. An example of this is found in the District Grocery Stores, Inc. in Washington, D. C.

There are approximately 400 grocery cooperatives in the United States, having a membership of more than $5^{0,000}$ retail stores. Some of the well known grocery cooperatives are the Red and White Corporation and the Independent Grocers Alliance of America. The twentieth century has also produced the hardware cooperative. Drug cooperatives were first organized in the late Eighties.

Cooperative retail oil companies play a large part in the petroleum field. The Cottonwood Oil Company is considered the first consumers' cooperative oil company in the country, having been started at Cottonwood, Minnesota, in r92I. The Freeborn County Cooperative Oil Company, of Minnesota, is one of the large cooperative retail distributors of petroleum products. The Trico Cooperative Oil Association is an association of local cooperatives, located in Cloquet, Minnesota. In 1946, the Midland Cooperative Wholesale purchased 440 acres of oil lands in Oklahoma, yielding 1,600 barrels of crude oil daily. The Farmers Union Central Exchange of St. Paul owns a cooperative petroleum refinery in Laurel, Montana. Other cooperatives in the oil field are Consumers Cooperative Association (Kansas); National Cooperative Refinery Association; Eastern Cooperative Wholesale (New York City); and Consumers Cooperatives Associated (Texas).

In the department store field, the $\mathrm{E}$. A. Filene Cooperative venture is said to be the first customer-owned department store in the United States. It is located in the Shirlington Shopping Center, in Arlington County, Virginia, near Washington, D. C., and was first opened in February, 1948. The store occupies a threestory building with 52,000 square feet of floor space and started with an inventory of about $\$ 250,000.00$. A similar cooperative is expected to be completed in 1948 in Providence, Rhode Island, and another is to begin in Irvington, New Jersey.

Cooperative retail stores are found everywhere. One of the largest in North America is the Cloquet Cooperative Society of Cloquet, Minnesota. The purpose, as expressed in the by-laws, is not only to furnish members with essentials of living but also to "aid in bringing about a complete change in the present system of production and distribution, and in developing a new and just system serving the interests of the community." The society also furnishes its members with the services of a credit union, a burial association, and an insurance agency.

The Cooperative 'Trading Company of Waukegan, Illinois, is both a producers' and consumers' cooperative dealing in basic food and automotive supplies. Another well-known store society is the Brule Cooperative Association, Brule, Wisconsin.

The American Indian has gone in for cooperation, too. Indian cooperatives to market the handicraft products of various tribes exist among the Winnebago Indian families in Wisconsin, the Navajos in New Mexico, and the Chippewa Indians in North Dakota.

Several million American motorists have built a non-profit service corporate institution in the American Automobile Association. Having no stockholders, the 
AAA devotes its revenues to providing a series of specialized services for a large segment of the car-owning public. ${ }^{\circ}$

In 1945 a group of labor-union, church, and other similar organizations decided that there should be a unified effort in purchasing goods so that individuals in the United States could ship packages with guaranteed delivery to specified persons abroad. A committee was appointed to investigate the best way to handle this, and after careful consideration accepted the plan of Dr. Lincoln Clark, now Professor of Business Administration, University of Tennessee, for a non-profit corporate entity (non-charitable). Accordingly, such an organization was set up under the laws of the District of Columbia under the name of Cooperative for American Remittances to Europe, commonly known as CARE. Formerly, single organizations and individuals could not get packages to friends and relatives in Europe, except at excessive cost and with extreme hazards. But by the use of this nonprofit corporate device, functioning as a procurement and shipping agent at cost, both individuals and institutions have reaped the benefits of efficient mass distribution, and Europe is receiving a demonstration of cooperative private enterprise in action in a capitalistic economy. ${ }^{7}$

The high cost of hospitalization has been one of the most troublesome factors in the family budget. Sociologists and economists have studied the problem for many decades. The middle-class American family has been perpetually under the hazard of financial liquidation by unexpected hospital and medical expenses. Today, through the non-profit corporate entity, with certain added insurance features, the medical profession and the hospitals can make their respective services available to the average individual and family at fair and reasonable fees. This is accomplished by the Blue Cross Hospital Plan, a non-profit cooperative service agency for securing hospital facilities for members. The individual hospitals from which services are obtained have also benefited. This plan has eliminated bad debts and made hospitalization a possibility for thousands who have never before had available anything but home facilities for recovery from sickness. The Blue Cross Hospital Plan is the largest non-profit cooperative in the world. From its incorporation in 1937, it had grown by October I, 1947, to a membership of nearly 29,000,000 in the United States, Puerto Rico, and Canada.

What is said to be the first cooperative hospital in the United States is the Farmers Union Cooperative Hospital Association, which owns and operates the Community Hospital of Elk City, Oklahoma, for the use of its members. The patient is charged on a basis sufficient to defray staff and hospital expenses and no

- See Charter and By-laws of the American Automobile Association, incorporated April 29, 19ro, Connecticut.

T"The Cooperative for American Remittances to Europe (CARE) is shipping individual food packages to persons in Europe the cost of which is paid for by donors in this country. CARE operates as a private, non-profit cooperative food distributor with the sanction and cooperation of the various governments. Its activities are proving daily that the efficiency of private business can be utilized in world relief distribution." Proceenings of THE Boston Conference on Distribution, 1946. See also, C.A.R.E., Inc., Fortune, Dec. 1947, p. 127 et seq. 
more. The forming of hospital associations was outstanding during 1946, especially in the territory west of the Mississippi River. At the end of 1945 , there were six cooperative hospitals operating, one each in Texas, Minnesota, Florida and Kansas, and two in Oklahoma; by the close of 1946 , there were at least nine cooperative hospitals actually operating and thirteen more were being formed. Twenty-two more are now planned in various states.

Group Health Association, Washington, D. C., is a well known cooperative operating a clinic and pharmacy. Originally organized to serve only federal employees, it adopted early in 1946 the open-membership principle on a group basis, serving Negroes as well as whites. The Association has purchased 20,000 square feet of land and plans to erect a medical center.

Closely allied to hospitals and medical care are the cemeteries. There are many cemetery and burial associations conducted on the non-profit basis. In some jurisdictions the declared policy of the law prevents the formation of cemetery associations for the purpose of making pecuniary profit either to the corporation or to its members. In such states the members cannot make a profit for themselves from the sale of lots or other revenue of the cemetery, nor can they make a gift of their revenue to another and independent corporation. ${ }^{8}$

In order to reduce the cost of funerals, there exists the Minnesota Valley Burial Association, the largest of the numerous burial associations located in Iowa, Minnesota, and South Dakota. In 1932, the Northwestern Cooperative Burial Association was chartered; it is composed of all the local cooperative burial associations in these three states. In $x 945$, there were forty-two farmers' non-profit burial associations serving an estimated 37,000 members or participants. ${ }^{9}$

Non-profit housing ventures are being undertaken all over the United States. ${ }^{10}$ Veterans, who have priority in the building field and the advantage of government loans and guarantees, are particularly active. In some places veterans are taking over the complete development of outlying tracts of land, including the installation of utilities, highways, streets, etc.; in others, they plan to take over existing buildings for redesigning or remodeling on a non-profit basis for the benefit of their tenant-association members. One association is backing homestead developments in Alaska. The Veterans' Co-operative Housing Association was the successful bidder in 1948 in the District of Columbia for Naylor Gardens-a 748-unit apartment development erected by the Federal Government during the last war. The project will be veteran-owned and -operated.

Planned housing units in general range in types from single-family dwellings on city lots to huge apartment buildings, and to subsistence homesteads with several acres of land. On one university campus, a students' cooperative composed of veterans is erecting prefabricated homes for themselves and their families.

\footnotetext{
${ }^{8}$ Brown v. Maplewood Cemetery Ass'n, 85 Minn. 498, 89 N. W. 872 (I902); Clark v. Rahway Cemetery, 69 N. J. Eq. 636, 5 I At. 26I (1905).

- Bull. No. 890, Bureau of Labor Statistics (U. S. Dep't Labor 1947).

${ }^{10}$ Nonprofit Housing in the United States, Bull. No. 896 , Bureau of Labor Statistics (U. S. Dep't Labor 1947).
} 
As early as 1932, the Amalgamated Clothing Workers' Union of New York City completed a new block of homes containing II5 apartments and having 426 rooms, located in the Bronx. During the period 1927-30, the union's non-profit housing activities provided living space for 857 families. Many labor groups are now fostering new housing developments on the non-profit plan. Examples are the printingtrade workers in Washington, D. C., and members of a local of U.A.W.-C.I.O. in South Bend, Indiana. Other housing developments on the cooperative basis are being started by members of labor unions in Racine, Wisconsin, and in other cities across the country.

In St. Paul and Minneapolis, a unique housing cooperative, consisting of three cooperators, one of whom owns the land, another being an architect, and the third a contractor, is building a complete village of 1200 acres on the home-inviting shores of a beautiful lake.

An outstanding cooperative project in urban development is now being undertaken by the East River Cooperative Apartments in lower Manhattan in the city of New York. It will provide 796 apartments in I2-story buildings that will occupy not over one-fourth of the land area of four blocks.

So extensive is the field of non-profit housing that in Chicago in May, 1946, a national conference of housing cooperatives authorized the creation of the National Cooperative Mutual Housing Association to work in harmony with other national cooperative associations, such as the Cooperative Congress, the Cooperative League, the Cooperative Finance Association, and National Cooperatives. The activities of these bodies cover the entire range of non-profit effort in the consumer field.

Students' cooperatives are becoming more and more popular. Cooperatives exist on many a college campus for furnishing rooms, meals, and school supplies. The University of California Students Cooperative Association in I933 commenced operations by serving meals and operating six houses for students. Since then it has purchased a large residential hotel which, with equipment, cost over $\$ 125,000$ and covers nearly half a city block.

At Seattle the Students Cooperative Association, whose members attend the University of Washington, has been organized; students at the University of Chicago formed the United Cooperative Projects, a federation, to perform various services for them; the University of Kansas Student Housing Association operates rooming and boarding houses for students. There are many more similar organizations throughout the collegiate world rendering excellent, faithful, and essential services to students on a non-profit basis.

Credit unions constitute one of the largest segments of non-profit corporations and associations. A credit union is a group of persons, associated in daily life, who agree to form an organization under either state or federal laws for the purpose of building up a fund with their savings in order to make needed loans, at reasonable interest rates, to members of the group. The group usually consists of employees of a single employer, such as workers in an office, store, manufacturing 
plant, railroad, or government agency. Of the latter, the Postal Credit Union of federal postal employees is an outstanding example. In some cases the common bond consists of membership in a church, a labor union, a cooperative, or merely residence in a small rural community.

The first credit union in the United States was created in 1909 in the Roman Catholic parish of Ste. Marie in Manchester, New Hampshire. The first state credit union law, or enabling act, for the organization and supervision of credit unions was that of Massachusetts in the same year. This Massachusetts legislation of 1909 is considered the foundation of the organized credit union movement in this country.

Religious bodies and churches have used credit unions extensively. About 575 credit unions have been formed among members of local churches in the United States and Canada. About $44^{6}$ of them are in Roman Catholic parishes, 88 in Protestant churches, I9 in Jewish congregations, and 22 within other religious groups. ${ }^{11}$

Federal credit unions are chartered and supervised by the Federal Deposit Insurance Corporation. ${ }^{12}$ In addition to the federal statutes, the laws of forty-four states and the District of Columbia now provide for the chartering of credit unions.

There are over Ix,700 credit unions now functioning in the United States and Canada. More than 9,000 of these are in the United States, with over 3,000,000 members who have accumulated more than $\$ 500,000,000$ in savings. Over two fifths of the active credit unions in the United States are federally chartered.

Credit unions are also known as "cooperative banks" or "people's banks." In Massachusetts, however, the term "cooperative banks" signifies incorporated bodies which elsewhere are known as building and loan associations.

Credit unions and commercial banks get along well together in our free economy. There is a division of labor between the two institutions. Credit unions generally cater to the short-term credit needs of people in the low-income brackets whom the commercial banks do not often serve; furthermore, the credit unions themselves maintain accounts in the banks.

Credit unions have rendered the greatest service in the field of small loans to borrowers of character. The annual charge collected by credit unions based on the rate for $\$$ I0o loans, is I2 per cent, whereas a few years ago the typical rate charged by personal loan departments of most banks was 17.3 per cent; remedial loan societies, 15.6 per cent to 18.9 per cent; installment buying, II per cent to 40 per cent and more; pawnshops, 36 per cent; unlicensed savings and loan associations, 28.5 per cent; personal finance companies, up to 42 per cent; unlicensed lenders, 240 per cent to 1000 per cent and more. ${ }^{13}$

One of the oldest of the people's business organizations is the farmers' mutual

${ }^{11}$ Benson Y. Landis, Trie Church and Credit Unions (pamphlet published by the Federal Council of Churches of Christ in America, 1947).

12 I947 Reorg. Plan No. I, $440 \mathrm{or}$, I2 FED. REg. 4534 (I947).

${ }^{13}$ Consumers Union Reports (May, 1936). 
insurance association, extending to almost every form of insurance-life, health and accident, automobile, home, furniture, hospital and medical, and fire. These companies are genuine "mutuals" and true cooperatives, unlike some of the large life insurance companies which are mutual in form but frequently not so in spirit. In r945 there were about two thousand farmers' mutual fire insurance companies, with over $\$ 1 \mathrm{r}, 000,000,000$ of insurance in force. A few of them have operated for over a hundred years and more than half of them have been in business over fifty years. In 1946, in Indiana, the Farm Bureau Fire \& Tornado Insurance Company was launched. The Ohio Farm Bureau insurance companies write fire, life, and automobile insurance in twelve states and the District of Columbia, employing over I,300 employees. Some other well known cooperative insurance companies are the Cooperators' Life Association (Minneapolis), Cooperators' Life Mutual (Wisconsin), Cooperative Mutual (Wisconsin Automobile Insurance Company), American Farmers' Mutual, The Workmen's Mutual Fire Insurance Society, Farmers' Automobile Inter-Insurance Exchange (Los Angeles), National Grange Mutual Liability Company (New Hampshire), and Great States Life Insurance Company (Illinois).

The numerous cooperative electric power companies are spearheaded by the activities of the federal Rural Electrification Administration. ${ }^{14}$ Through self-liquidating loans, REA provides roo per cent financing for constructing rural electric facilities to serve rural people who do not have central station electric service. The law provides that, in making such loans, preference shall be given to public bodies, cooperatives, and non-profit or limited-dividend associations. ${ }^{15}$

During the fiscal year 1947, Congress had authorized loan funds totaling approximately $\$ 1,075,628,000$, of which more than $\$ 1,000,000,000$ had been allocated to over 1,000 borrowers by the third quarter of the fiscal year 1947, for the construction of electric distribution, generation, and transmission facilities and for the purchase and installation of electrical appliances. REA also provides engineering and legal consultation and other assistance to new borrowers.

In 1946 , according to the REA, there were 918 farmer cooperative electric power and light associations in the United States with an estimated membership or participation exceeding $1,549,056$.

The latest figures for farmers' mutual telephone companies are those of r937, issued by the Bureau of the Census, according to which there then were 32,879 such cooperative associations in the United States, serving over 669,344 participants.

According to the 1940 census there were 4,356 mutual non-profit irrigation companies in the country. Where there is no offer or holding out to the public and the

\footnotetext{
14 The REA was created by Executive Order No. 7037 of May 11, 1935, under authority of the Emergency Relief Appropriation Act of 1935, approved April 8, 1935 (49 STAT. II5). Statutory provision for the agency was made in the Rural Electrification Act of May 20, 1936 (49 STAT. 1363, 7 U.S.C. \$\$90I-914). It was made a part of the federal Department of Agriculture in 1939. In 1944 Congress liberalized the terms of REA loans and removed the time limitation from its lending program (58 STAT. 739, 7 U.S.C. \$903 (Supp. I946)).

${ }^{15}$ United States Government Mandal (2d ed. 1947), Government Information Service, Office of Government Reports, Washington, D. C.
} 
service is extended only to certain individuals as a matter of accommodation or for particular reasons, the supplying of water for irrigation is not deemed a public use. Accordingly a mutual cooperative water company is not subject to the jurisdiction of a public utility commission; nor may it exercise the prerogative of eminent domain. ${ }^{16}$

The radio cooperative is a newcomer to non-profit enterprise. Ohio's farmers have long protested against what they considered hurried and inadequate radio programs. Accordingly, WRFD, Ohio's first rural radio station, was created, backed by more than 55,000 members of the Ohio Farm Bureau Federation. The station began serving the farmers on September 27, 1947. ${ }^{17}$ There is only one other known licensed radio cooperative-the Potomac Cooperative Federation. It does not yet have its radio in operation, but ground was broken for its transmitter station in October, I947..$^{18}$

Throughout this discussion reference has been made to these non-profit businesses as "corporations." It should be remembered that in many instances such businesses are not incorporated, but function under various statutes as "associations," "societies," and the like, enjoying a quasi-corporate status. The use of the word "association" or "society" gives no indication whether the business is incorporated or not. For the most part these organizations are incorporated, except in cases such as the American Institute of Banking and the New York Stock Exchange.

The non-profit commercial corporation is not a cure-all for the ills of business. It must be operated as efficiently as a profit corporation because it definitely is an agent acting in the role of securing individual profits or savings for its members. It is, however, a lawful agency which a multitude of individuals, partnerships, and corporations may effectively and profitably use in the performance of a segment of their business activities. It should be viewed as. a corporate tool to be used jointly with others when needed. If an organization is large enough to handle its own off-premise business in such a way as to meet competition and secure volume prices, then there is no need for it to become part of any non-profit corporate venture. On the other hand, the American economy is largely predicated upon small ownership and individual operation of businesses. In servicing the mediumsized operations, it is increasingly important to utilize the non-profit corporation

${ }^{11}$ De Pauw University v. Public Service Commission of Oregon, 247 Fed. I83 (D. Ore. 1917), 253 Fed. 848 (D. Ore. 19r8); Southern California Edison Co. v. Railroad Commission of California, I94 Cal. 757, 230 Pac. 66r (r924). See also the Carey Act, 4I STAT. I085 (1921), as amended, 43 U.S.C. 5641 ef seq. (1940). It has been held that a non-profit cooperative corporation supplying electric service to its members only is not a public service corporation and therefore not subject to regulation by the Commission. Inland Empire Rural Electrification v. Department of Public Service of Washington, 199 Wash. 527, 92 P. 2d 258 (1939); Garkane Power Co. v. Public Service Commission, 98 Utah 466, 100 P. 2d 57x (1940); Department of Public Utilities v. R. O. McConnell, I98 Ark. 502, 130 S.W. 2d 9 (1939); William MEade Fietcher, Cyclopedia of the Law of Private Corporations 568 et seq. (Perm. ed. 193I).

17 News for Farmer Cooperatives, p. 5, Jan. 1948.

1s Letter dated February 13, 1948, from Ewan Clague, Commissoner of Labor Statistics, U. S. Dep't Labor, Washington, D. C., to the authors. 
to obtain for these individual units the efficiency and service enjoyed by members of a mass integrated organization. This peculiarly democratic corporation may be used in such a manner that individual ownership and operation of home and business will be made more attractive and secure. Many large organizations also find that the public can be better served by using such a joint corporate structure for certain services the costs of which would be excessive if performed severally.

One of the best defenses of the American businessman against the inroads of undue state regulation in the field of individual initiative lies in the joint use of a corporation created to serve as agent, without profit, in the rendering of essential services which he can neither afford nor accomplish by himself. 